\title{
LIFE IN HOT SPRINGS AND HYDROTHERMAL VENTS*
}

\author{
ANDREAS H. SEGERER, SIGFRIED BURGGRAF, GERHARD FIALA, GERTRUD \\ HUBER, ROBERT HUBER, URSULA PLEY, and KARLO. STETTER \\ Lehrssuhl für Mikrobiologie. Universität Regensburg. Universitätsstr. 31. D-8400 Regensburg. Federal \\ Republic of Germany
}

(Received 6 August, 1992)

\begin{abstract}
Hot springs and hydrothermal systems occurring within volcanic areas are inhabited by hyperthermophilic microorganisms, some of which grow at temperatures up to $110^{\circ} \mathrm{C}$. Hyperthermophiles grow anaerobically or aerobically by diverse metabolic types. Within the high temperature ecocystems, primary production is independent from solar energy.
\end{abstract}

\section{Introduction}

Microbiological exploration of extreme biotopes has recently led to the discovery of unusual hyperthermophilic organisms with optimum growth temperatures of at least $80^{\circ} \mathrm{C}$ occurring in volcanic habitats. Some hyperthermophiles are able to grow up to $110^{\circ} \mathrm{C}$. In contrast, the upper temperature limit of usual thermophilic and extremely thermophilic prokaryotes, which have been recognized since a long time, is usually in the range of $60-80^{\circ} \mathrm{C}$. This paper will give an overview about the hyperthermophiles. The reader is also referred to other general reviews on hyperthermophiles (Setter, 1989a; Stetter et al., 1990; Segerer et al., 1991a) and reviews focussing on specified hyperthermophilic taxa (R. Huber and Stetter, 199la; R. Huber and Stetter, 1991b; Segerer and Stetter, 1991a; Segerer and Stetter, 1991b) which have been published recently.

\section{Habitats}

Hyperthermophiles have almost exclusively been isolated from volcanic habitats, i.e. continental solfatara fields and submarine hydrothermal areas (Corliss et al., 1979; Williams and McBirney, 1979). A few isolates were also obtained from suitable anthropogenic biotopes.

Within solfataras, hyperthermophiles occur in sulfur-rich boiling springs, mudholes, and heated soils. Solfataric springs are either highly acidic and rich in sulfate or almost neutral, sometimes even slightly alkaline, reflecting the chemical composition of the ground (Brock, 1978). Depending on the altitude above sea level,

- Presented at the Session . Water in- the Solar System and lis Role in Exobiology during the 26th Gineral Assembly of the Eurupean Geophysical Socicty, 22-26 april 1991 in Wiesbaden. Germany. 
the temperatures can be as high as $100^{\circ} \mathrm{C}$. The soils exhibit a bilayered profile which is defined by $\mathrm{pH}$ value and redox state (Stetter et al., 1986a; Stetter et al., 1986b): (a) The surface layer is typically about $30 \mathrm{~cm}$ thick, highly acidic (pH 0.5-4), and oxidized. Ferric iron compounds cause a rusty appearance. (b) The lower zone is essentially anaerobic due to the permanent stream of volcanic exhalations containing reducing compounds (e.g., $\mathrm{H}_{2} \mathrm{~S}$ ). Characteristically, the pH value is significantly higher than in the oxidized layer ( $\mathrm{pH} 4-8)$. The color is blackischgrey due to the presence of heavy metal sulfides. Both zones are rich in molecular sulfur which is generated by the reaction of $\mathrm{H}_{2} \mathrm{~S}$ with $\mathrm{SO}_{2}$ or $\mathrm{O}_{2}$. Solfataric hyperthermophiles are well adapted to their environment. There are both extreme acidophiles and neutrophiles which thrive aerobically, facultatively anaerobically, or strictly anaerobically (see section on physiology below). No hyperhermophiles could be isolated from highly acidic wet fumaroles at Stromboli and Fossa volcano (Southern Italy) and Hawaii, possibly due to their high content of $\mathrm{SO}_{2}$ and $\mathrm{HCl}$ which are toxic to laboratory cultures in higher concentrations (A.H.S. and K.O.S, unpublished results; T.D. Brock, personal communication).

The marine biotopes include anaerobic hot sediments, submarine fumaroles and hydrothermal vents. These habitats usually exhibit $\mathrm{pH}$ values close to neutrality (pH 5-8.5). Due to the elevated hydrostatic pressure, the temperatures of the hot waters may exceed $100^{\circ} \mathrm{C}$. Vent systems occurring at ocean floor spreading zones discharge hydrothermal fluids into the surrounding seawater which are rich in sulfides and heavy metals and may exhibit temperatures of up to almost $400^{\circ} \mathrm{C}$ (Corliss et al., 1979; Jannasch and Wirsen, 1979; Jannasch, 1989).

Presumably due to their different chemical composition, marine and terrestric high temperature biotopes are each colonized by characteristic, distinct communities of hyperthermophiles. As an exception, some isolates of the solfataric species Acidianus infernus and Thermoplasma volcanium could be obtained from highly acidic sãñ ỳna rine sediments off Vulcano Island, Italy (Segerer et al 1986, 1988).

Anthropogenic habitats include heated overflow waters from geothermal power plants (Stetter, 1985; R. Huber et al., 1987), acidic hot water drainages and soils self-heated coal refuse piles (Darland et al., 1970; Brock, 1978; Marsh and Norris, 1985 ) and from a uranium mine containing graphite and pyrite in eastern Germany (A.H.S. and K.O.S., unpublished observation).

\section{Taxonomy and Phylogeny}

To date, about 45 species of hyperthermophiles and related extreme thermophiles have been described and assigned to a number of different genera and orders (Table I). All hyperthermophiles but the Thermotogales belong to the archaeal domein (Woese et al., 1990) of life which had previously been disignated 'archaebacteria' (Woese et al., 1978). Based on sequence analyses of I6S rRNA genes and paralogous genes that deverged from each orher before the domains emerged from their common ancestor, the Archaea were shown to represent a distinct monophyletic lineage of 
TABLE I

Taxonomy of hyperthermophiles and related thermophiles

\begin{tabular}{|c|c|c|c|}
\hline Order & Genus & Species & Reference \\
\hline \multicolumn{4}{|c|}{ Domain Archaea (Kingdom Crenarchaeora) } \\
\hline \multirow[t]{10}{*}{ Sulfolobales } & Sulfolobus & S. acidocaldarius & Brock et al., (1972) \\
\hline & & S. solfararicus & Zillig et al., 1980 \\
\hline & & S. shibarae & Grogan et al., 1991 \\
\hline & & S. meiallicus & G. Huber and Stetter, 1991 \\
\hline & Merallosphaera & 1. sedulab & G. Huber et al., $1989^{\circ}$ \\
\hline & Sulfurococcus & Sc. mirabilis & $\begin{array}{l}\text { Golovacheva et al., 1987; Zhilina } \\
\text { et al., } 1989\end{array}$ \\
\hline & Acidianus & f. infernus & Segerer et al., 1986 \\
\hline & & A. brierley. & $\begin{array}{l}\text { Zillig et al., 1980, Segerer et al., } \\
1986\end{array}$ \\
\hline & Desulfurolobus & D. ambivalens & Zillig et al., 1986 \\
\hline & Stygiolobus & Stl. azoricus & Segerer et al., 1991b \\
\hline \multirow[t]{12}{*}{ Thermoproteales } & Thermoproteus & T. tenax & Zillig et al., 1981 \\
\hline & & T. neutrophilus & Stetter, 1986; Zillig, 1989 \\
\hline & & T. uzoniensis & Bonch-Osmolovskaya et al., 1990 \\
\hline & Pyrobaculum & Pb. islandicum & R. Huber et al., 1987 \\
\hline & & Pb. organorrophum & R. Huber et al. 1987 \\
\hline & Thermofilum & Tf. pendens & Zillig et al., 1983a \\
\hline & & Tf. librum & Stetter, 1986 \\
\hline & Desulfurococcus & DC. mucosus & Zillig et al., 1982 \\
\hline & & Dc. mobilis & Zillig et al., 1982 \\
\hline & & Dc. saccharovorans & Stetter, 1986 \\
\hline & & De. amylolysicus & Bonch-Osmolovskaya et al., 1985 \\
\hline & Staphylothermus & Su. maritimus & Fiala et al., 1986 \\
\hline \multirow[t]{4}{*}{ 'Pyrodictiales' } & Pyrodictium & Pd. occultum & Stetter et al., 1983 \\
\hline & & Pd. brockii & Stetter et al., 1983 \\
\hline & & Pd. ab!issi & Pley et al., 1991 \\
\hline & Hyperthermus & H. burvlicus & Zillig er al., 1990 \\
\hline \multirow{6}{*}{$\begin{array}{l}\text { Thlom Evryarchüecta) } \\
\text { Thermocodcales }\end{array}$} & Thermodiscus & Td. maritimus & Stetter, 1986 \\
\hline & Thermococcus & Tc. celer & Zillig et al., 1983b \\
\hline & & Tc. litoralis & Neuner et al., 1990 \\
\hline & & Tc. stetteri & Miroshnickenko et al., 1989 \\
\hline & Pyrococcus & Pc. furiosus & Fiala and Stetter, 1986 \\
\hline & & Pc. woesei & Zillig et al., 1987 \\
\hline \multirow[t]{2}{*}{ Archaeoglobales ${ }^{\circ}$} & Archaeoglobus & Ag. fulgidus & Stetter et al., 1987; Stetter, 1988 \\
\hline & & Ag. profundus & Burggraf et al., $1990 \mathrm{~b}$ \\
\hline \multirow[t]{2}{*}{ Thermoplasmatales' } & Thermoplasma & Tp. acidophilumb & Darland et al., 1970 \\
\hline & & Tp. volcaniumb & Segerer et al., 1988 \\
\hline Methanopyrales' & Methanopyrus & Mp. kandleri & R. Huber et al., 1989a \\
\hline \multirow{3}{*}{$\begin{array}{l}\text { Methanopyrates } \\
\text { Methanococcales }\end{array}$} & Methanococcusa & Mc. jannaschii & Jones el al., 1983 \\
\hline & & Mc. igneus & Burggraf et al., 1990a \\
\hline & . & $\begin{array}{l}\text { Hc. thermolitho- } \\
\text { trophicus }\end{array}$ & H. Huber et al., 1982 \\
\hline \multirow[t]{2}{*}{ Aethanobacteriales' } & Methanothermus & Mi. Servidus & Stetter et al., 1981 \\
\hline & & 1/t. Sociabilis & Lauercr et al.. 1986 \\
\hline
\end{tabular}


Table I (continued).

\begin{tabular}{|c|c|c|c|}
\hline Order & Genus & Species & Reference \\
\hline \multicolumn{4}{|l|}{ Domain Bacteria } \\
\hline Thermorozales & $\begin{array}{l}\text { Thermosipho } \\
\text { Fervidobacterium }\end{array}$ & $\begin{array}{l}\text { Tt. maritima } \\
T t . \text { neapolitana } \\
T t . \text { thermarum }^{\mathrm{b}} \\
\text { Ts. africanus } \\
\text { F. nodosum } \\
\text { F. islandicumb }\end{array}$ & $\begin{array}{l}\text { R. Huber et al., } 1986 \\
\text { Jannasch et al., } 1988 \\
\text { Windberger et al., } 1989 \\
\text { R. Huber et al., } 19896 \\
\text { Patel et al., } 1985 \\
\text { R. Huber et al., } 1990 \mathrm{~b}\end{array}$ \\
\hline
\end{tabular}

- The order or genus contains further mesophilic organisms which are not listed here.

b Thermophilic but not hyperthermophilic organism, mentioned due to relationship to hyperthermophiles.

evolution beside the domeins Bacteria (after recognition of archaebacteria designated as 'eubacteria') and Eucarya (eukaryotes) (Woese and Fox, 1977; Fox et al., 1980; Woese, 1987; Gogarten et al., 1989; Iwabe et al., 1989; Woese et al., 1990).

The archaeal phylogenetic tree consists of two main branches (kingdoms) (Woese et al., 1990): (a) The Crenarchaeota which almost exclusively include hyperthermophiles (Stetter and Zillig, 1985; R. Huber and Stetter, 1991a; Segerer and Stetter, $1991 \mathrm{~b}$ ); and (b) the Euryarchaeota. The first crenarchael organisms discovered in the 70 s and early 80 s were sulfur metabolizers and either extreme acidophiles (e.g., Sulfolobus acidocaldarius) or acid tolerant (e.g., Thermoproteus tenax) (Brock et al., 1972; Zillig et al., 1980; 1981). Therefore, the whole group has sometimes been called 'thermoacidophilic' or 'sulfurdependent' archaebacteria (Zillig et al., 1981; Stetter and Zillig, 1985). However, a number of isolates are now known to be either not dependent on sulfur, neutrophilic, or both. Hence, these designations are no longer appropriate. In contrast to the Crenarchaeota, the Euryarchaeota represent a phenotypically highly diverse group of organisms including methanogens, sulfate reducers, extreme halophiles, thermcacidophiles, and fermentative archaea, only some of which are thermophilic or hyperthermophilic (Woese, 1987).

The only hyperthermophilic bacteria recognized to date are included within the order Thermotogales (R. Huber and Stetter, 199lb). By 16S rRNA sequences, this order represents the deepest branch of the bacterial phylogenetic tree (Woese, 1987).

\section{Morphology, Physiology and Distribution}

The hyperthermophilic archaea and Thermotoga usually are of the size of a typical prokaryotic cell $(\varnothing \approx 0.5-2 \mu \mathrm{m})$ e.g., Figures $1-4)$ and employ a variety of different morphotypes, including rods (Thermoproteus, Pyrobaculum, Methanopyrus, Methanothermus) (Figure 1), thin filaments $(\varnothing \approx 0.1 \mu \mathrm{m}$; Thermofilum), discs (Pyrodictium, Thermodiscus) (Figure 2) and cocci (most hyperthermophiles) (Figures 3, 4). The cocci may be more or less regularly or highly irregularly in shape, depending on the organism (Stetter et al., 1990; Table II). Highly irregular, lobed cells are characteristic of most members of the Sulfolobales (Brock et al., 1972; Stetter, 


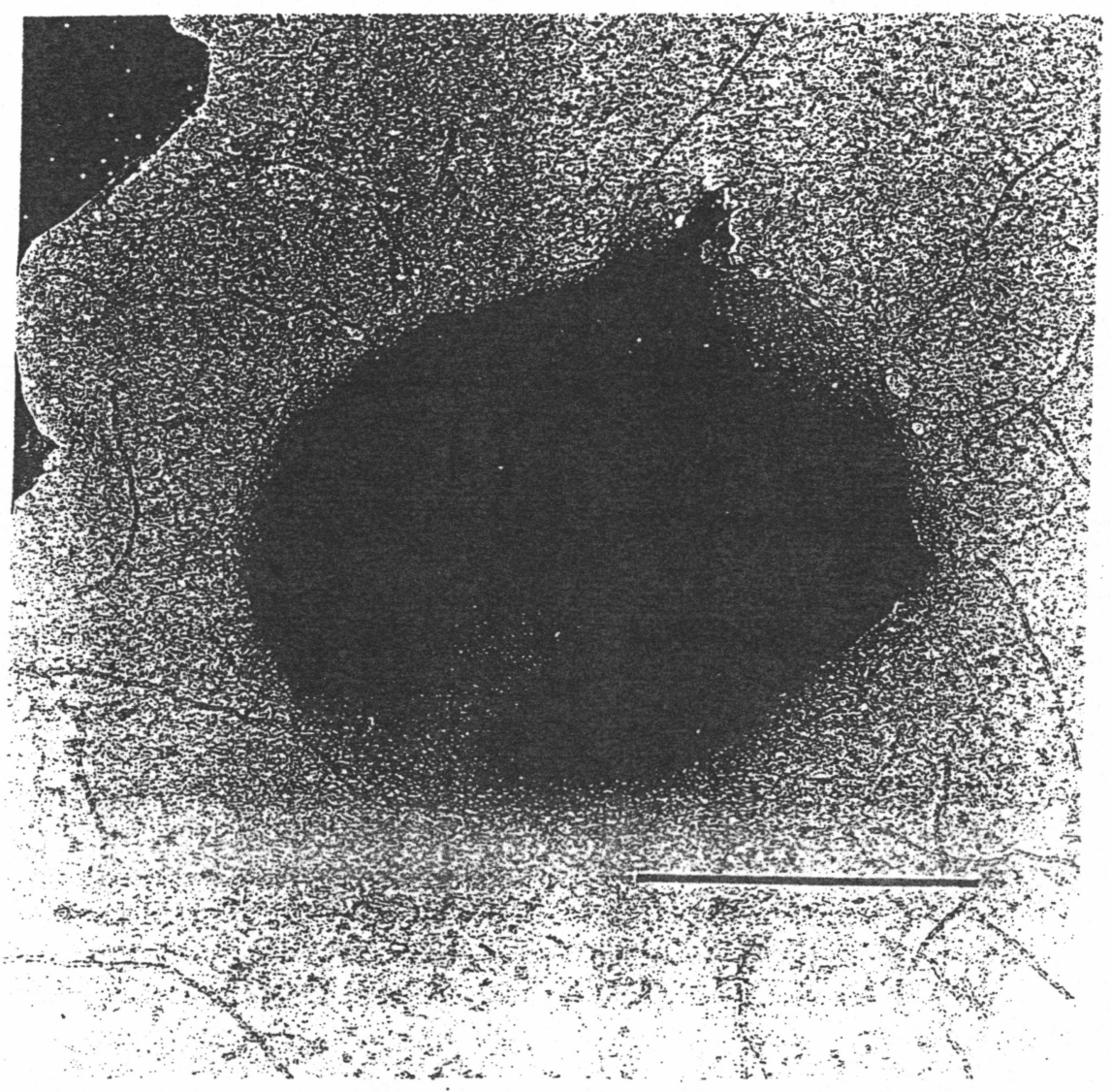

Fig. 3. Stygiollobus azoricus isolate FC6. EM micrograph, Pt shadowing. Bar $0.5 \mu \mathrm{m}$.

sheath-like outer membrane ballooning over both ends (R. Huber et al., 1986; Jannasch et al., 1988; Rachel et al., 1990).

Most hyperthermophiles are flagellated (e.g., Figure 4), but are usually immotile at room temperature and run only at temperatures of $\geq 50^{\circ} \mathrm{C}(\mathrm{R}$. Huber et al., 1987; Grogan, 1989; R.H. and K.O.S., unpublished obeservations).

Whereas the majority of hyperthermophiles thrive optimally at $\mathrm{pH}$ values around neutrality, the members of the Sulfolobales (and the less extremely thermophilic Thermoplasma spp.) are extreme acidophiles that grow optimally around $\mathrm{pH} 2-$ 3 and lyse at $\mathrm{pH} \geq 7$ (Darland et al., 1970; Brock et al., 1972; Segerer et al., 1988; Segerer and Stetter, 1991b) (Table II). With the exception of Stygiclobus (Segerer et al., 1991b), all of these acidophiles are able to grow aerobically (Segerer and Stetter, 1991a, b; Table II). All other hyperthermophiles are extreme anaerobes which are usually killed even by traces of oxygen. Special techniques are required for successful cultivation, therefore (Balch et al., 1979). No dormant stages like 


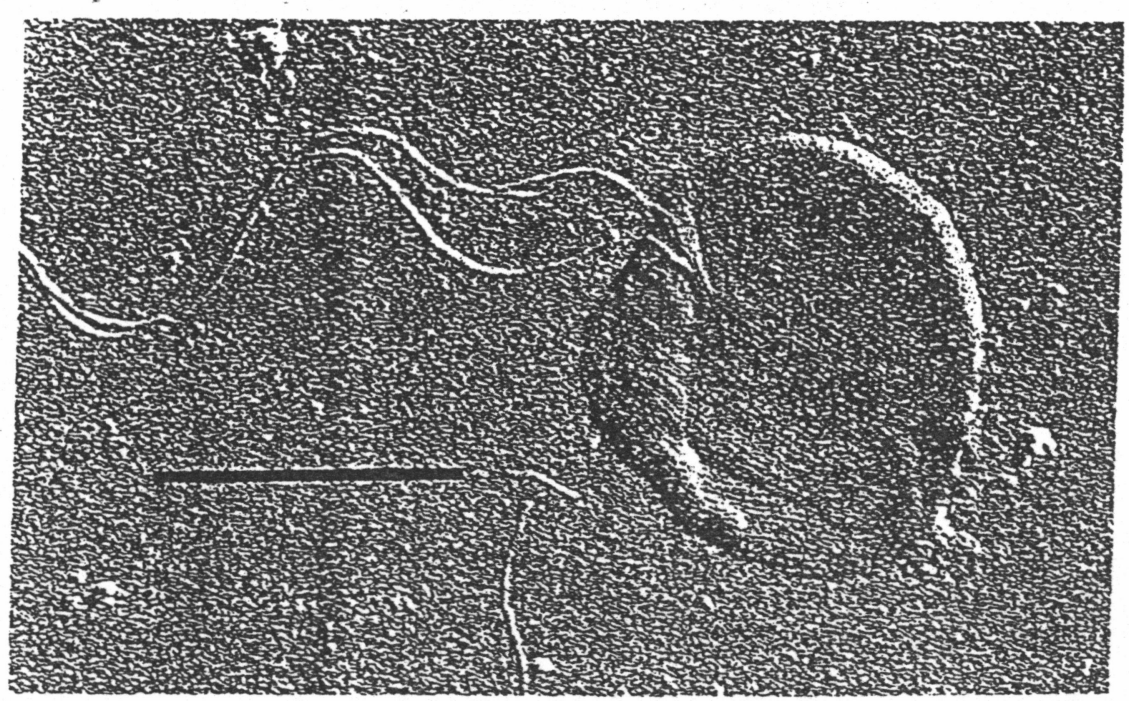

Fig. 4. Archaeoglobees fulgidus isolate Vc 16. EM micrograph, Pt shadowing. Bar, $0.5 \mu \mathrm{m}$.

endospores are formed by the hyperthermophiles known to date.

As a rule, hyperthermophiles have an optimum growth temperature well above $80^{\circ} \mathrm{C}$ and cannot grow below $\approx 60^{\circ} \mathrm{C}$. Methanopyrus (Figure 1) and Pyrodictium (Figure 2) are the most thermophilic organisms known, growing maximally at $110^{\circ} \mathrm{C}$ and being unable to grow below $80^{\circ} \mathrm{C}$ (Stetter et al., 1983; Pley et al., 1991; R.

\section{TABLE II}

Morphological and physiological properties of some hyperthermophiles

\begin{tabular}{|c|c|c|c|c|c|c|}
\hline \multirow{2}{*}{ Species } & \multirow{2}{*}{ Morphology } & \multicolumn{3}{|c|}{$\begin{array}{l}\text { Growth temperature } \\
\left({ }^{\circ} \mathrm{C}\right)\end{array}$} & \multirow{2}{*}{$\begin{array}{l}\text { Growth } \\
\text { at } \mathrm{pH}\end{array}$} & \multirow{2}{*}{$\begin{array}{l}\text { anaero- } \\
\text { bic (an)/ } \\
\text { aerobic (ae) }\end{array}$} \\
\hline & & Min. & Opt. & Max. & & \\
\hline Acidianus infernus & lobed, irregular cocci & 60 & 88 & 95 & $0.8-5.5$ & $\mathrm{ae} / \mathrm{an}$ \\
\hline $\begin{array}{l}\text { Pyrobaculum } \\
\text { islandicum }\end{array}$ & $\begin{array}{l}\text { rods, sometimes with } \\
\text { terminal spherical }\end{array}$ & 74 & 100 & 103 & $5-7$ & an \\
\hline Thermofilum pendens & $\begin{array}{l}\text { protrusions } \\
\text { thin filaments, sometimes } \\
\text { with a terminal spherical } \\
\text { protrusions }\end{array}$ & 70 & 88 & 95 & $4-6.5$ & an \\
\hline Pyrodictium occultum & discs with fibres & 82 & 105 & 110 & $5-7$ & an \\
\hline Pyrococcus furiosus & cocci & 70 & 100 & 103 & $5-9$ & an \\
\hline Archaeoglobus fulgidus & irregular cocci & 60 & 83 & 95 & $5.5-7.5$ & an \\
\hline Methanococcus igneus & irregular zocci & 4.5 & 88 & $9 !$ & $5-7.5$ & an \\
\hline Methanorhermus sociabilis & rods in clusters & 65 & 88 & 97 & $5.5-7.5$ & an \\
\hline Methanofyrus kandleri & rods & 84 & 98 & 110 & $5.5-7$ & an \\
\hline Thermologa maritima & $\begin{array}{l}\text { rods with a sheath-like } \\
\text { outer membrane ('toga') }\end{array}$ & 55 & 80 & 90 & $5.5-9$ & an \\
\hline
\end{tabular}


Huber et al., 1989a; Table II). The temperature optimum of $P d$. occultum and $P d$. brockii at $105^{\circ} \mathrm{C}$ (under slight overpressure) is the highest one of any organism described so far (Stetter, 1982). Hyperthermophiles cannot grow at low temperatures, but survive in the cold (e.g., at $4^{\circ} \mathrm{C}$ ) at moderately acidic or neutral $\mathrm{pH}$ values at least for years. At least some anaerobic hyperthermophiles are able to tolerate oxygen stress significantly better at low temperatures than at growth temperature (Fiala et al., 1986; R. Huber et al., 1987). This property is most probably essential for their dispersal through cold, oxidized areas. Evidently, volcanic eruptions are a major source of their propagation. In-field studies demonstrated the presence of $>10^{6}$ viable anaerobic hyperthermophilic archaea per liter of seawater within the eruption plume of Macdonald seamount (Polynesia, Southern Pacific) at a distance of $1 \mathrm{~km}$ from the active crater (R. Huber et al., 1990a).

\section{Metabolism}

Some hyperthermophiles (e.g., Figures 1-4) grow chemolithoautotrophically on inorganic energy sources and $\mathrm{CO}_{2}$ as sole carbon source. From an ecological point of view, these organisms can be considered as primary producers of organic matter within the high temperature ecosystems (Figure 5). Some of them are able to grow faculatively heterotrophically and/or to use a variety of electron donors and acceptors, thus being metabolically versatile. Possibly, this property is important for efficient competition within the ecosystem. The hyperthermophilic methanogens (e.g., Figure 1) and Stygiolobus azoricus (Figure 3) are probably highly specialized, growing obiligately autotrophically by only one means of energy yielding reaction (methanogenesis and $\mathrm{H}_{2}-\mathrm{S}^{0}$ lithoautotrophy, respectively; see below). Four types of chemolithoautotrophic metabolism have been recognized (Figure 5): (1) The formation of $\mathrm{H}_{2} \mathrm{SO}_{4}$ by oxidizing molecular sulfur $\left(\mathrm{S}^{0}\right)$ is characteristic of most Sulfolobales (Shivvers and Brock, 1973; Stetter, 1989b; Segerer and Stetter, 1991b). Usually, oxygen serves as terminal acceptor of electrons. However, most if not all $\mathrm{S}^{0}$-oxidizing species are able to use molybdate and ferric iron as alternative electron sinks and can thus be considered to be facultative anaerobes (Brock and Gustafson, 1976; Brierley and Brierley, 1982). Many species are able to use sulfide (including sulfidic ores), tetrathionate and/or ferric iron as alternative energy sources (Brierley and Murr, 1973; Brierley and Brierley, 1973; Brock et al., 1976; G. Huber et al., 1986; Wood et al., 1987). (2) Some species (Figure 5) of the orders Sulfolobales, Thermoproteales and 'Pyrodictiales' grow by the reduction of $\mathrm{S}^{0}$ to $\mathrm{H}_{2} \mathrm{~S}$ by means of $\mathrm{H}_{2}\left(\mathrm{H}_{2}-\mathrm{S}^{0}\right.$ lithoautotrophy; Fischer et al., 1983). Acidianus spp. and the closely related Desulfurolobus ambivalens are unique in being capable of facultatively growing by oxidation or reduction of $\mathrm{S}^{0}$, depending on the growth conditions (Segerer $c t$ al., 1985; Zillig et al., 1985). (3) The marine sulfate reducing archaecn, Archaeog'obris fulgidus(Figure 4), is able to grow facultatively autotrophically by the reduction of thiosulfate with $\mathrm{H}_{2}$ by means of a not yet elucidated pathway (Stetter, 1988). (4) The hyperthermophilic methanogens produce $\mathrm{CH}_{4}$ exclusively from $\mathrm{CO}_{2}$ plus 


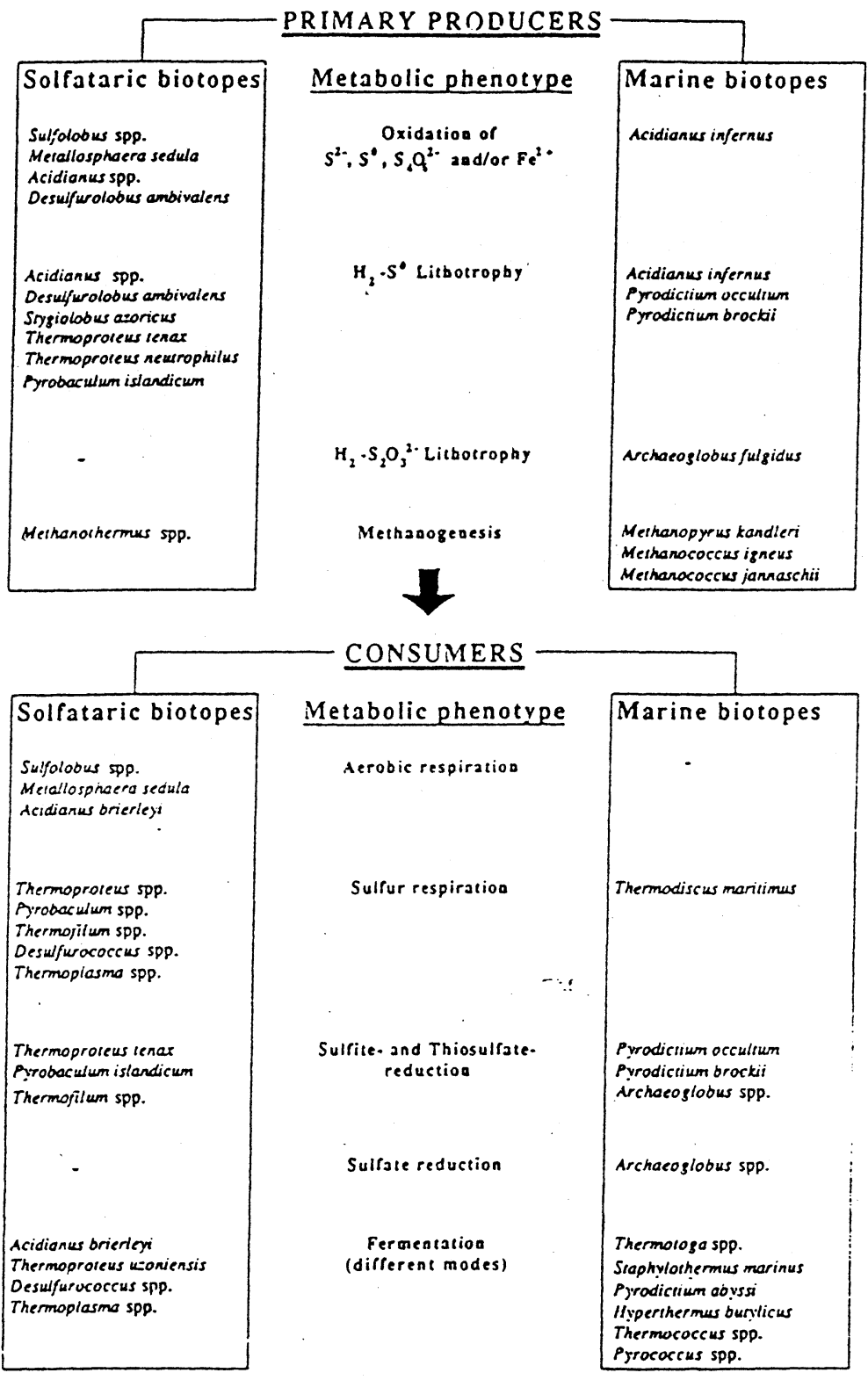

Fig. 5. Metabolism of terrestric and marine hyperthermophiles and food chain within the high temperature ecusystems. 
$\mathrm{H}_{2}$ (Stetter et al., 1981; Jones et al., 1983; Lauerer et al., 1986; R. Huber et al., 1989a; Burggraf et al., 1990a).

The biomass produced by the autotrophs is consumed by heterotrophic hyperthermophiles growing on organic material (Figure 5). There are both chemolithoheterotrophic (= mixotropic) and chemoorganotrophic organisms. Pyrodictium occultum and $P$ d. brockii are able to grow facultatively mixotrophically by reducing thiosulfate ( $P d$. occultum) and sulfite $\left(P d\right.$. brockii) with $\mathrm{H}_{2}$ in the presence of organic substrate (König et al., 1988; Stetter et al., 1990; Pley et al., 1991). Archaeoglobus profundus grows obligately mixotrophically by reducing sulfate, sulfite or thiosulfate with $\mathrm{H}_{2}$ (Burggraf et al., 1990b). The matabolic types of the organotrophs include: (1) aerobic respiration, which is typical for some Sulfolobales (Brock et al., 1972; Lübben et al., 1989; Segerer and Stetter, 1991b); (2) sulfur respiration (Pfennig and Biebl, 1976) which is employed by several members of the Thermoproteales (some of which are also able to reduce sulfite and thiosulfate) (R. Huber and Stetter, 1991a), 'Pyrodictiales' (Stetter, 1986), and the less thermophilic Thermoplasmaspp. (Segerer et al., 1988); (3) the reduction of sulfate, sulfate and thiosulfate which is a characteristic of Archaeoglobus fulgidus (Stetter et al., 1987); and (4) various modes of fermentation. With the exception of Thermoplasma (Budgen and Danson, 1986; Danson, 1988) and Pyrococcus (Schäfer and Schönheit, 1991), the fermentative pathways have not yet been elucidated in detail. Some of the fermentative organisms possess $\mathrm{H}_{2}$ evolving hydrogenases (Adams, 1990). In the presence of $\mathrm{S}^{0}$, however, no $\mathrm{H}_{2}$ is formed, but electrons are channelled to a sulfur reductase, forming $\mathrm{H}_{2} \mathrm{~S}$ in a non-energy yielding reaction (Zillig et al., 1983b; Fiala and Stetter, 1986; Adams, 1990; R. Huber and Stetter, 1991b; Schäfer and Schönheit, 1991). This reaction is probably of biological significance, as $\mathrm{H}_{2}$ is a strong inhibitor of growth of these organisms.

\section{The Upper Temperature Limit of Life}

At the growth temperature of hyperthermophiles, essential cell components of mesophiles and usual thermophiles like enzymes, nucleic acids and membranes, become rapidly denatured. Hyperthermophiles, however, are highly adapted to high temperatures and cannot even grow below $60-80^{\circ} \mathrm{C}$. Hence, some principles must exist conferring stabilization and/or optimal conformation to essential cell components of hyperthermophiles. Although there are some clues, these principles are still very poorly understood.

Hyperthermophiles contain histone-like proteins and reverse gyrase, the action of which possibly stabilizes the double helix of DNA (Searcy, 1975; Thomm et al 1982; Kikuchi and Asai, 1984; Reddy and Suryanarayana, 1988; de la Tour et al., 1990). In addition Methanopyrus and Methanothermus contain a high intracellular salt concentration (Methanopyrus: 3.3 moles $\mathrm{L}^{-i}$ potassium cyclo 2,3-diphospinoglycerate) (Hensel and König, 1988; R. Huber et al., 1989a) which could also contribute to thermal stabilization of the double helix. Possibly, the numercus 
posttranscriptional base modifications occurring in the RNA of all hyperthermophiles studied thus far confer thermostability to these molecules (Edwards et al., 1991).

Purified enzymes and proteins of hyperthermophiles are highly thermophilic and thermostable. For example, anaerobically grown Acidianus spp. contain a $\mathrm{H}_{2}$ oxidizing hydrogenase which exhibits an optimum turnover rate of $117^{\circ} \mathrm{C}$ in vitro and does not loose activity (in the presence of hydrogen) when incubated several hours at $110^{\circ} \mathrm{C}$ (A.H.S. et al., manuscript in preparation). The thermostability of this and many other hyperthermophilic proteins characterized to date is an intrinsic property of the polypeptides (Jaenicke and Zavodszky; 1990). In addition, hyperthermophilic methanogens stabilize some enzymes by potassium cyclo-2,3-diphosphoglycerate (Hensel and König, 1988).

Acidophilic hyperthermophiles have to cope with a highly acidic environment in addition to temperature stress. These organisms generally thrive by extruding protons, thus keeping their interior $\mathrm{pH}$ close to neutrality (Hsung and Haug, 1975; Searcy, 1976; Lübben and Schäfer, 1989; Matin. 1990). The mechanism of stabilization of their exterior cell structures against is not understood. As the cells lyse at $\mathrm{pH} \geq 7$, protons seem to be specifically required for structural maintenance of cellular stability (Smith et al., 1973).

The upper temperature limit at which life can exist is still unclear. Since the stability of some amino acids and low molecular weight compounds like ATP and NAD rapidly decreases at temperatures above $100^{\circ} \mathrm{C}$ (Bernhardt et al., 1984), hyperthermophiles can most probably live only at temperatures allowing resynthesis of thermolable compounds at a rate sufficiently higher than the rate of their thermal destruction (Stetter et al., 1986a; Fiala et al., 1986). Because of this limitation, the upper temperature border of life may possibly be found between 110 and $150^{\circ} \mathrm{C}$.

\section{Conclusions}

Thermophilic and hyperthermophilic organisms occur in numerous phylogenetically highly divergent lineages of evolution and could therefore represent an ancient phenotype already existing since billions of years (Achenbach-Richter et al., 1987; Woese, 1987). Recently, a theory of a thermophilic chemolithoautotrophic origin of life has been worked out (Wächtershäuser, 1988: Wächtershäuser, 1990). Within the complex communities of hyperthermophilic organisms existing in volcanic habitats, primary production of organic matter occurs at temperatures of up to $110^{\circ} \mathrm{C}$. The metabolism of anaerobic chemolithoautotrophic hyperthermophiles is based on the consumption of $\mathrm{H}_{2}, \mathrm{CO}_{2}$ and inorganic sulfur compounds, or, in case of the methanogens, on $\mathrm{H}_{2}$ and $\mathrm{CO}_{2}$ alone. These compounds may be formed exclusively within the volcanic habitat. Hence, the organisms are uncoupled from the global life cycle which is dependent on the input of solar energy. Rather, they depend on planetary energy and could in principle also exist outside the terrestrial ecosphere (provided that liquid water and a terrestrial kind of volcanism are present). With respect to the instability of biomolecules at high temperatures, 'black smoker' 
conditions $\left(250^{\circ} \mathrm{C} ; 260 \mathrm{bar}\right)$ are highly unlikely to be compatible with life (Baross and Deming, 1983; Bernhard et al., 1984; Trent et al., 1984; White, 1984).

\section{References}

Achenbach-Richter, L., Gupta, R., Setter, K. O., and Woese, C. R.: 1987, System. Appl. Microbiol. 9, 34

Adams, M. W. W.: 1990, FEMS Micrabiol. Rev. 75, 307.

Balch, W. E., Fox, G. E., Magrum, L. J., Woese, C. R., and Wolfe, R. S.: 1979, Microbiol. Rev. 43. 260.

Baross, J. A. and Deming, J. W.: 1983, Narure 303, 423.

Bernhardt, G., Lüdemann, H. D., Jaenicke, R., König, H., and Stetter, K. O.: 1984, Naturwissenschaften 71, 583.

Bonch-Osmolovskaya, E. A., Slesarev, A. I., Miroshnichenko, M. L., Svetlichnaya, T. P., and Alexeev. V. A.: Microbiologiya 57, 78.

Bonch-Osmolowskaya, E. A., Miroshnichenko, M. L., Kostrikina, N. A., Chernych, N. A., and Zavarzin. G. A.: 1990; Arch. Microbiol. 154, 556.

Brierly, C. L. and Brieriey, J. A.: 1973, Can. J. Microbiol. 19, 183.

Brierley, C. L. and Brierley, J. A.: 1982, Zentralbl. Bakteriol. Parasitenkd. Infekrionskr. Hyg. Abt. I Orig. Reihe C 3, 289.

Brierley, C. L. and Murr, L. E.: 1973, Science 179, 488.

Brock, T. D.: 1978, Thermophilic Microorganisms and Life at High Temperatures, Springer Veriag. Berlin.

Brock. T. D. and Gustafson, J.: 1976, Appl. Environ. Microbiol. 32, 567.

Brock, T. D., Brock, K. M., Belly, R. T., and Weiss, R. L.: 1972, Arch. Mikrobiol. 84, 54.

Brock, T. D., Cook, S., Peterson, S., and Mosser, J. L.: 1976, Geochim. Cosmochim. Acta 40, 493.

Budgen, N. and Danson, M. J.: 1986, FEBS Lett. 196, 207.

Burggraf, S., Fricke, H., Neuner, A., Kristjansson, J. K., Rouvier, P., Mandeicon, L., Woese, C. R.. and Stetter, K. O.: 1990a, System. Appl. Microbiol. 13, 263.

Burggraf, S., Jannasch, H. W., Nicolaus, B., and Stetter, K. O.: 1990b, System. Appl. Microbiol. 13. 24.

Corliss, J. B., Dymond, J., Gordon, L. I., Edmond, J. M., von Herzen, R. P., Ballard, R. D., Green. K., Williams, D., Bainbridge, A., Crane, K., and van Andel, T. H.: 1979, Science 203, 1073.

Danson, M. J.: 1988, Adv. Microbiol. Physiol. 29, 165.

Darland, G., Brock, T. D., Samsonoff, W., and Conti, S. F.: 1970, Science 170, 1416.

de la Tour, B. C., Portemer, C., Nadal, M., Stetter, K. O., Forterte, P., and Duguet, M.: 1990. J. Bacteriol. 172, 6803.

Edmonds, C. G., Crain, P. E., Gupta, R., Hashizume, T., Hocart, C. H., Kowalak, J. A., Pomeraniz. S. C., Stetter, K. O., and McCloskey, J. A.: 1991, J. Bacteriol. 173, 3138.

Fiala, G. and Stetter, K. O.: 1986, Arch. Microbiol. 145, 56.

Fiala, G., Stetter, K. O., Jannasch, H. W., Langworthy, T. A., and Madon. J.: 1986. System Appl. Micrbiol. 8, 106.

Fischer, F., Zillig, W., Stetter, K. O., and Schreiber, G.: 1983, Nature 301, 511.

Fox, G. E., Stackebrandt, E., Hespell; R. ., Gibson, J., Maniloff, J., Dyer, T. A.. Wolfe, R. S., Balch. W. E., Tanner, R. S., Magrum, L. J., Zablen, L. B., Blakemore, R., Gupta, R., Bonen, L., Levis. B. J., Stahl, D. A., Luehrsen, K. R., Chen, K. N., and Woese, C. R.: 1980, Science 209, 457.

Gogarten, J. P., Kibak, H., Dittrich, P., Taiz, L., Bowman, E. .J., Bowman, B. J., Manolson, M. F.. Poole. R. J., Date, T., Oshima, T., Konishi, J., Denda, K., and Yoshida, M.: 1989, Proc. Natl. Acad. Sci. USA 86, 6661.

Golovachevam, R. S., Zhukova, I. G., Nikultseva, T. P., and Ostrovinskii. D. N.: 1987. Mikrubiologiva 56. 281.

Grogan. D. W.: 1989, J. Bacteriol. 171, 6710.

Grogan, D. W., Palm, P., and Zillig. W.: 1990. Arch. Microbiol. 154, 594.

Hensel, R. and König, H.: 1988, FEMS Microbiol. Lelt. 49, 75.

Hsung, J. C. and Haug, A.: 1975, Biochim. Biophys. Acro 389, 477. 
Huther, G. and Stetter, K. O.: 1991. System. Appl. Microbiol. 14, in the press.

Huber, G., Huber, H., and Stetter, K. O.: 1986, Biolech. Bioeng. SYmp. 16, 239.

Huber, G., Spinnler, C., Gambacorta, A., and Stetter, K. O.: 1989, System. Appl. Microbiol. 12, 38.

Huber, H., Thomm, M., König, H., Thies, G., and Stetter, K. O.: 1982, Arcít. Microbiol. 132, 47.

Hiuber, R. and Stetter, K. O.: 1991a, in The Prokaryotes. A Handbook on the Biology of Bacteria. Ecophysiology. Isolation, Identification, Applications, 2nd edition, Springer Verlag. New York. Chapter 28 (in the press).

Huber, R. and Stetter, K. O.: 1991b, in The Therophiles, CRC Press, Chapter 7 (in the press).

Huber, R., Langworthy, T. A., König. H., Thomm, M., Woese, C. R., SLeytr, U. B., and Stetter, K. O.: 1986, Arch. Microbiol. 144, 324.

Huber, R., Kristjansson, J. K., and Stetter, K. O.: 1987, Arch. Microbiol. 149, 95.

Huber, R., Kurr, M., Jannsch, H. W., and Stetter, K. O.: 1989a, Nature 342, 833.

Huber, R., Woese, C. R., Langworthy, T. A., Fricke, H., and Stetter, K. O.: 1989b, System. Appl. Microbiol. 12, 32.

Huber, R., Stoffers, P., Cheminee, J. L., Richnow, H. H., and Stetter, K. O.: 1990a, Nature 345, 179.

Huber, R., Woese, C. R., Langworthy, T. A., Kristjansson, J. K., and Stetter, K. O.: 1990b, Arch. Microbiol. 154, 105.

Iwabe, N., Kuma, K., Hasegawa, M., Osawa, S., and Miyata, T.: 1989, Proc. Natl. Acad. Sci. USA 86,9355 .

Jaenicke, R. and Zavodszky, P.: 1990, FEBS Lett. 268, 344.

Jannasch, H. W.: 1989, in Autotrophic Bacteria, Science Tech Publ., Madison, and Springer Verlag, Berlin, p. 147.

Jannasch, H. W. and Wirsen, C. O.: 1979, Bioscience 29, 592.

Jannasch, H. W., Huber, R., Belkin, S., and Stetter, K. O.: 1988, Arch. Microbiol. 150, 103.

Jones, W. J., Leigh, J. A., Maver, F., Woese, C. R., and Wolfe, R. S.: Arch. Microbiol. 136, 254.

Kikuchi, A. and Asai, K.: 1984, Nature 304, 677.

König, H., Messner, P., and Stetter, K. O.: 1988, FEMSS Microbiol. Lett. 49, 207.

Lauerer, G., Kristjansson, J. K., Langworthy, T. A., König, H., and Stetter, K. O.: 1986, System Appl. Microbiol. 8, 100.

Lübben, M. and Schäfer, G.: 1989, J. Bacteriol. 171, 6106.

Marsh, R. M. and Norris, R. P.: 1985, FEMS Microbiol. Lett. 17, 322.

Matin, A.: 1990, FEMS Microbiol. Rev. 75. 307.

Miroshnichenko, M. L., Bonchh-Osmolovskaya, E. A., Neuner, A., Kostrikina, N. A., Chernych, N. A., and Alekseev, V. A.: 1989, System. Appl. Micrubiol. 12, 257.

Nuener, A., Jannasch, H. W., Belkin, S., and Stetter, K. O.: 1990, Arch. Microbiol. 153, 205.

Patel, B. K. C., Morgan, H. W., and Daniel, R. M.: 1985, Arch. Microbiol. 141, 63.

Pfenning, N. and Biebl, H.: 1976, Arch. Microbiol. 110, 3.

Pley, U., Schipka, J., Gambacorta, A., Jannasch, H. W., Fricke, H., Rachel, R., and Stetter, K. O.: 1991, System. Appl. Microbiol. 14, 245.

Rachel, R., Engel, A. M., Huber, R.. Stetter, K. O., and Baumeister, W.: 1990, FEBS Lett. 262, 64.

Reddy, T. R. and Suryanarayana, T.: 1988, Biochim. Biophys. Acla 949, 87.

Schäfer, T. and Schönheit. P.: 1991, Arch. Microbiol. 155, 366.

Searcy, D. G.: 1975, Biochim. Biophys. Acta 395, 535.

Searcy, D. G.: 1976, Biochim. Biophys. Acta 451, 278.

Segerer, A. and Stetter, K. O.: 1991a, in The Prokaryoles. A Handbook on the Biology of Bacteria. Ecophysiology. Isclation. Identification. Applications, Ind edition, Springer Verlag, New York, Chapter 20 (in press).

Segerer, A. and Stetter. K. O.: 199lb, in The Prokiaryoles. A Handbook on the Biology of Bacteria. Ecophysiology. Isolation. Identification. Applications, 2nd edition, Springer Verlag, New York, Chapter 28a (in press).

Segerer, A., Klink, F., and Stetter, K. O.: 1985, Noture 313, 787.

Scgeier, A.. Ncuner, A.. Kristjansson. J. K., and Stetler, K. O.: 1986, Int. J. System. Bacteriol. 36, 5.59.

Segerer, A., Langworthy, T. L.. and Stetter, K. O.: 1988, System. Appl. Micobiol. 10, 161.

Segerer, A. H., Huber, R., and Stetter, K. O.: 19913. Biologie in unserer Zeit 21 (in press). 
Segerer, A., Trincone, A., Gahriz, M., and Stetter, K. O.: 19916, Int. J. System. Bacteriol. 41 (in press). Shivvers, D. W. and Brock. T. D.: 1973, J. Bacteriol. 114, 706.

Simith, P. F.. Langworthy, T. A., Mayberry, W. R., and Hougland, A. E.: 1973, J. Bacteriol. 116, 1019

Stciter. K. O.: 1982, Nature 300, 258.

Stetter, K. O.: 1985, Naturwissenschaften 72, 291.

Stetter, K. O.: 1986, in Thermophiles: Genercl. Moiecular and Applied Microbiology, Wiley and Sons, New York, p. 39.

Stetter, K. O.: 1988, System. Appl. Microbiol. 10, 172.

Stetter, K. O.: 1989a, in Autotrophic Bacteria, Science Tech Publ., Madison, and Springer Verlag, Berlin, p. 167.

Stetter, K. O.: 1989b, in Bergey's Manual of Systemaric Bacteriology, vol. 3, Williams and Wilkins, Baltimore, p. 2250.

Stetter, K. O. and Zillig, W.: 1985, in The Bacteria, vol. 8, Academic Press, San Diego (CA); p. 85.

Stetter, K. O., Thomm, M., Winter, J., Wild̈gruber, G., Huber, H., Zillig. W., Janekovic, D., König, H., Palm, P., and Wunderl, S.: 1981, Zentralbl. Bakieriol. Parasitenkd. Infekltionskr. Hyg. Abt. I Orig. Reihe C 2, 166.

Stetter, K. O., König, H., and Stackebrandt, E.: 1983, System. Appl. Microbiol. 4, 535.

Stetter, K. O., Fiala, G., Huber, R., and Segerer, A.: 1986a, Experientia 42, 1187.

Stetter. K. O., Segerer, A., Zillig, W., Huber, G., Fiala, G.. Huber, R., and König, H.: 1986b, System. Appl. Microbiol. 7, 393.

Stetter, K. O., Lauerer, G., Thomm, M., and Neuner, A.: 1987. Science 236, 822.

Stetter, K. O., Fiala, G., Huber, G., Huber, R., and Segerer, A.: 1990, FEMS Microbiol. Rev. $75,117$.

Thomm. M., Stetter, K. O., and Zillig, W.: 1982, Zentralbl. Bakteriol. Parasitenkd. Infekstionskr. Hyg. Abt. I Orig. Reihe C 3, 128.

Trent, J. D., Chastain, R. A., and Yayanos, A. A.: 1984, Nature 207, 737.

Wächtershäuser, G.: 1988, Microbiol. Rev. 52, 452.

Wächtershäuser, G.: 1990, Origins of Life 20, 173.

White, R. H.: 1984, Nature 310, 430.

Williams, H. and McBirney, A. R.: 1979, Volcanology, Freeman and Cooper, San Franciso.

Windberger, E., Huber, R., Trincone, A., Fricke, H., and Stetter, K. O.: 1989, Arch. Microbiol. 151, 506.

Woese, C. R.: 1987, Microbiol. Rev. 51, 221.

Woese, C. R. and Fox, G. E.: 1977, Proc. Natl. Acad. Sci. USA 74, 5088.

Woese, C. R., Manilon, J., and Fox, G. E.: 1978, J. Mol. Evol. 11, 245.

Woese, C. R., Kandler, O., and Wheelis, M. L.: 1990, Proc. Norl. Acad. Sci. USA 87, 4576.

Wood, A. P., Kelly, D. P., and Norris, P. R.: 1987, Arch. Microbiol. 146, 382.

Zhilina, N. V., Severina, L. O., and Golovacheva, R. S.: 1989. Mikrobiologiya 58, 36.

Zillig. W.: 1989. in Bergey's Manual of Systematic Bacteriolog.; Vol. 3, Williams and Wilkins, Baltimore, p. 2241 .

Zillig. W., Stetter, K. O., Schulz, W., Priess, H., and Scholz. I.: 1980, Arch. Microbiol. 125, 259.

Zillig. IV., Stctter, K. O., Schäfer, W., Janekovic, D., Wunderl. S., Holz, I., and Palm, P.: 1981, Zentralbl. Batiteriol. Parasitentid. Infekitionskir. Hyg. Abt. I Orig.. Reihe C 2, 205.

Zillig. W., Stetter. K. O., Prangishvilli, D., Schäfer, W.. Wunderl, S., Janekovic, D., Holz, I., and Palm, P.: 1982, Zentralbl. Bakteriol. Parasitenkd. Infektionskr. Hyg. Abt. I Orig. Reihe C 3, 304.

Zillig, W., Gierl, A., Schreiber, G., Wunderl, S., Janekovic. D.. Stetter, K. O., and Klenk, H. P.: 1983a, Sysrem. Appl. Microbiol. 4, 79.

Zillig. W., Holz, I., Janekovic, D., Schäfer, W., and Reiter. W. D.: 1983b, System. Appl. Microbiol. 4. 88 .

Zillig. W., Yeats, S., Holz, I., Böck, A., Gropp. F., Rettenberger, M., and Lutz, S.: 1985, Nature 313. 789.

Zillig. W.. Yeats, S., Holz, I., Böck. A., Reltcriburger, M.. Gropp, F., and Simon. G.: Sy'stem. Appl. Mficrobiol. 8. 197.

Zillig. W.. Holz., I., Klenk, H. P., Trent, J., Wunderl, S., Janckovic, D., Erwin, J., and Halas, B.: 1987. Sịsı'm. Appl. Microbiol. 9, 62.

Zillig. W., Holz, 1., Janckovic, D., Klenk, H. P., Imscl, E.. Trent, J., Wunderl. S., Forjatz, V. H.. Coutiaho, R., and Ferricira, T.: 1990, J. Bucteriol. 172. 3959. 